\title{
Habitat use by Callicebus coimbrai (Primates: Pitheciidae) and sympatric species in the fragmented landscape of the Atlantic Forest of southern Sergipe, Brazil
}

\author{
Renata Rocha Déda Chagas ${ }^{1,3} \&$ Stephen F. Ferrari²
}

\author{
${ }^{1}$ Programa de Pós-graduação em Desenvolvimento e Meio Ambiente, Universidade Federal de Sergipe, Avenida Marechal \\ Rondon, Jardim Rosa Elze, 49.100-000 São Cristóvão, SE, Brazil. \\ ${ }^{2}$ Departamento de Biologia, Universidade Federal de Sergipe. Avenida Marechal Rondon, Jardim Rosa Elze, 49100-000 São \\ Cristóvão, SE, Brazil. \\ ${ }^{3}$ Corresponding author. E-mail: renata_deda118@hotmail.com
}

\begin{abstract}
Anthropogenic habitat fragmentation is a chronic problem throughout the Brazilian Atlantic Forest biome. In the present study, four forest fragments of 60-120 ha were surveyed on a rural property in southern Sergipe, where two endangered primate species, Callicebus coimbrai Kobayashi \& Langguth, 1999 and Cebus xanthosternos Wied-Neuwied, 1826 , are found. Two transects were established in each fragment, and the predominant habitat in $50 \mathrm{~m}$ sectors was assigned to one of three categories (mature forest, secondary forest and anthropogenic forest). Standard line transect surveys of the resident primate populations - which included a third species, Callitrhix jacchus Linnaeus, 1758 - were conducted, with a total of $476 \mathrm{~km}$ walked transect, resulting in 164 primate sightings. At each sighting of a primate, the habitat class was recorded and the height of the individual above the ground was estimated. The analysis indicated a significant $(p<0.05)$ preference for mature forest in $C$. xanthosternos which was also observed more frequently in the larger and better preserved fragments. No clear habitat preference was verified in the other two species, although both were relatively more abundant in the smaller fragments. However, a tendency to avoid anthropogenic forest was observed in C. coimbrai. Callitrhix jacchus used significantly lower $(\mathrm{p}<0.05)$ forest strata than the other species, although other differences were unclear, presumably because of the reduced stature of the forest in the fragments. Overall, the results of the study indicate that $C$. xanthosternos is tolerant of the effects of habitat fragmentation, and that differential habitat use may play an important role in niche partitioning.
\end{abstract}

KEY WORDS. Callithrix jacchus; Cebus xanthosternos; interspecific competition; niche partitioning.

The Neotropical monkeys (Platyrrhini) are strictly arboreal, and are thus especially vulnerable to the effects of habitat fragmentation (Blomeuist et al. 2009, Arroyo-Rodriguez \& Dias 2010). Differential habitat preferences and especially vertical stratification (Terborgh 1983, Porter 2004) play an important role in niche partitioning, principally in closely-related or ecologically-similar taxa. These factors may be accentuated in the context of habitat fragmentation, where the alteration of the distribution of resources may exacerbate interspecific competition, which often results in the local extinction of some species (FerRari et al. 2003).

Titi monkeys (Callicebus spp.) are found in a wide variety of Neotropical ecosystems, ranging from the terra firme forests of the Amazon and Orinoco basins, through the scrub woodlands of the Paraguayan Chaco, the Brazilian Caatinga and the Atlantic Forest of southeastern Brazil (Defler 1994, Marinho-Filho \& Veríssimo 1997, Palacios et al. 1997, van Roosmalen et al. 2002). In their review of the genus, van RoOSMALEN et al. (2002) defined five species groups: the Callicebus donacophilus (d'Orbigny, 1836), Callicebus cupreus (Spix, 1823), Callicebus moloch (Hoffmannsegg, 1807), Callicebus torquatus (Hoffmannsegg, 1807), and Callicebus personatus (É. Geoffroy Saint-Hilaire, 1812). The personatus group is the only one distributed wholly outside the Amazon basin. Its five species are found in eastern Brazil, as far south and west as the Tietê-Paraná-Parnaíba river system, and as far north as the São Francisco river. This includes the southeastern portion of the Caatinga biome, which is inhabited by Callicebus barbarabrownae Hershkovitz, 1990 (R.C. Printes, Universidade Federal de Minas Gerais, unpubl. data).

The endangered titi Callicebus coimbrai Kobayashi \& Langguth, 1999, occupies the northern most extreme of the distribution of the genus in the Atlantic Forest, a region characterized by intense deforestation and habitat fragmentation (CoImbra-Filho \& Câmara 1996). While the species was originally thought to be extremely rare and restricted to a small handful of sites (Kobayashi \& LANGGUTH 1999), recent surveys 
(JerusALINSKy et al. 2006, Sousa et al. 2008) have revealed that it occurs at a number of dozen localities in Sergipe and northern Bahia, some of which are fragments of less than ten hectares. This reinforces the conclusion that C. coimbrai, like most other titis (e.g. Ferrari et al. 2000, Heiduck 2002), is relatively tolerant of habitat fragmentation, although there are still no specific data on habitat use in this species.

While the main focus of the study was C. coimbrai, two other platyrrhines also occur at the site, and were recorded relatively frequently. One of these species, the yellow-breasted capuchin, Cebus xanthosternos Wied-Neuwied, 1826, is listed as critically endangered by the IUCN (KIERULFF et al. 2008), and is relatively rare in Sergipe (R. Beltrão-Mendes, Universidade Federal de Sergipe unpubl. data), where it is poorly-known. The third species is the common marmoset, Callitrhix jacchus Linnaeus, 1758, a widespread and common platyrrhine relatively well-adapted to habitat disturbance (Sussman \& KInZeY 1984, Digby et al. 2007).

The three species present potentially meaningful differences in body size and ecological adaptations, although all three tend towards omnivory, and are also relatively tolerant of habitat fragmentation. With a body weight of approximately $1.2 \mathrm{~kg}$ (KobaYashi \& LANGgUTH 1999), C. coimbrai is intermediate in size between C. jacchus (300-400 g; unpubl. data) and C. xanthosternos (2-3 kg, JACK 2007). Like other Atlantic Forest titis, C. coimbrai is predominantly frugivorous (J.P. Souza-Alves, Universidade Federal de Sergipe, unpubl. data), while C. jacchus is gummivorousinsectivorous (Digry et al. 2007), and capuchins also tend to be relatively insectivorous (JACK 2007).

In the present study, populations of all three species were surveyed at a site in southern Sergipe characterized by the typical regional pattern of habitat fragmentation. This permitted an analysis of interspecific differences in habitat preferences, which provided insights into their ecological relationships and niche partitioning in the context of habitat fragmentation.

\section{MATERIAL AND METHODS}

The present study took place at the Fazenda Trapsa $\left(11^{\circ}\right.$ $\left.12^{\prime} \mathrm{S}, 37^{\circ} 14^{\prime} \mathrm{W}\right)$, an abandoned shrimp farm in Itaporanga d'Ajuda, in the south of the Brazilian state of Sergipe. The farm's forest reserve consists of a complex of eight fragments of Atlantic Forest with an area varying from 60 to 120 ha (Fig. 1), with a total area of 500 ha, which vary considerably in terms of habitat quality, shape and connectivity. Due to its proximity to the coast, the local ecosystem can be classified as an arboreal restinga, which

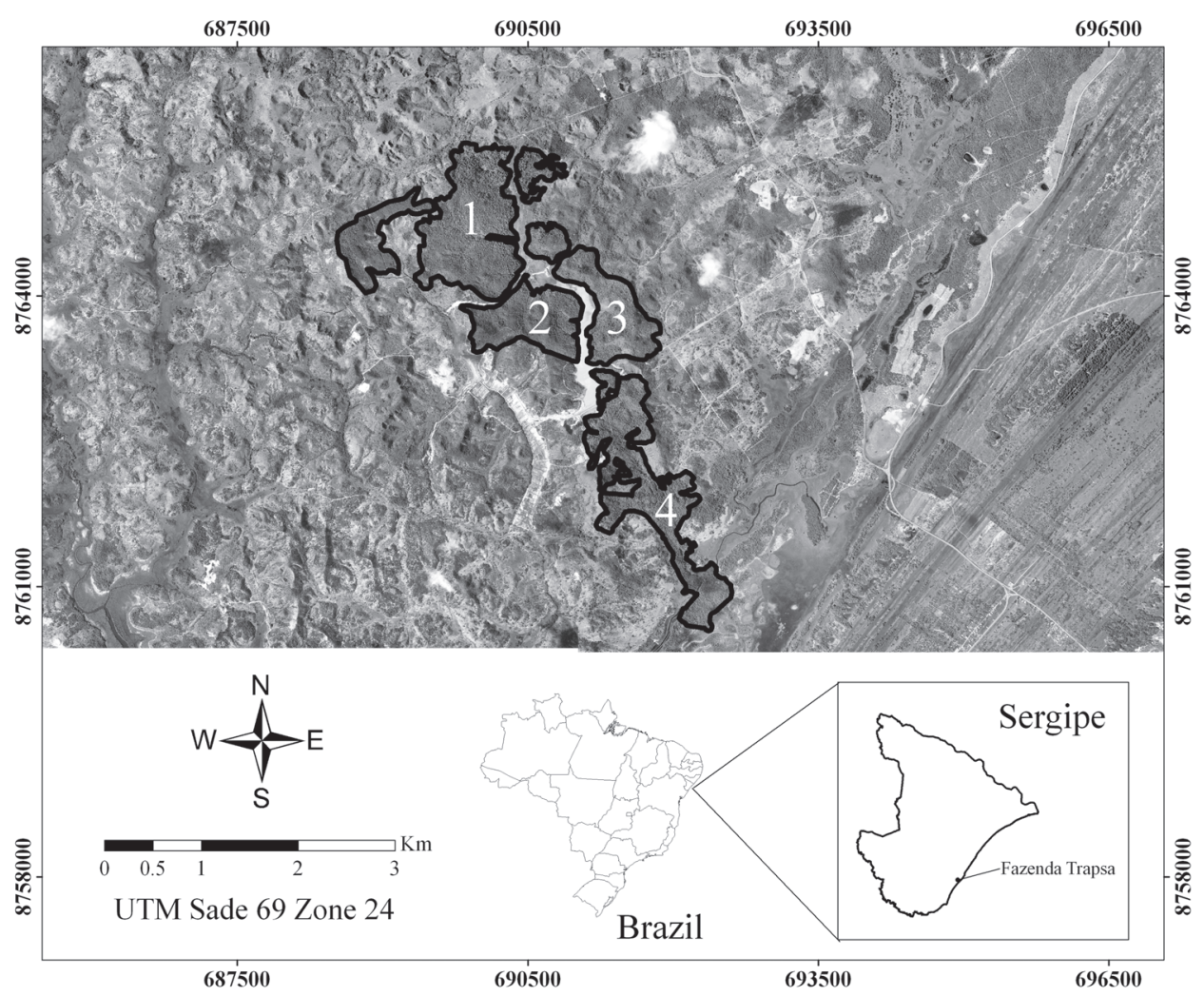

Figure 1. Aerial photograph of the Fazenda Trapsa, Sergipe, showing the four fragments surveyed in the present study (numbered - see table II). The striated area in the east is the coastal plain. 
is similar to the inland Atlantic Forest in terms of species composition (SCARANO 2002), but is characterized by vegetation of relatively low stature (canopy of approximately $15 \mathrm{~m}$ ) located on extremely sandy soils related to coastal dune systems.

In addition to its fragmentation, the remaining forest at the study site has suffered a series of impacts in the past, including selective logging. While direct impacts (including hunting) have ceased in recent years, there have been occasional fires, and a large proportion of Fragment 2 was severely affected by a fire in 1997. The size, shape and history of each fragment create a unique mosaic of habitats.

The first step in the classification of habitats was the definition of three main habitat types (Tab. I, Figs 2-4), using categories adapted from CAlouro \& Pires (2004). The trails established in each fragment for the line transects were then walked and each $50 \mathrm{~m}$ interval was allocated to one of the three categories, according to the dominant vegetation type observed along the trail within the interval. This resulted in the classification of the relative availability of the different types of habitat along each trail system, presumed to be a representative sample of the fragment as a whole.

Mammal populations were surveyed in the four largest fragments using standard line transects procedures (BUCKLAND et al. 2001). Two transects were established in each fragment, located according to its topography. The trails were arranged in such a way as to provide the most representative sample possible of the vegetation. The straight-line trails established in each fragment were walked carefully at a speed of 1.0-1.5 $\mathrm{km} / \mathrm{h}$, and at each encounter with any nonvolant mammal, the species was recorded, together with a standardized set of data. For the present study, only the records of the position of the sighting in relation to the trail system (which was marked at $50 \mathrm{~m}$ intervals) and the height above the ground of the animal were analyzed. Surveys were carried out weekly between April and October, 2008, with between 73 and $182 \mathrm{~km}$ walked in a given fragment, and an overall total of $476 \mathrm{~km}$.

For the analysis of habitat use, the location of each sighting on the trail system was cross-referenced with the habitat category recorded for the respective interval. The number of records of a given species assigned to each category was then compared with the number expected according to the availability (proportion) of each category. The number of records expected for category $i$ was found by $c_{i} \cdot n$, where $c_{i}=$ the overall proportion of category $i$, and $n=$ the total number of records collected for the species. Observed and expected values for each species were compared using Chi-square. In the specific case of Callicebus Thomas, 1903, the same procedure was applied to the analysis of habitat use in each of the four fragments.

The use of vertical space was based on the analysis of height records, which were assigned to six 3 m classes, based on a prior assessment of the distribution of the data. Differences among species in the distribution of vertical records were evaluated using the Kruskal-Wallis nonparametric analysis of variance.

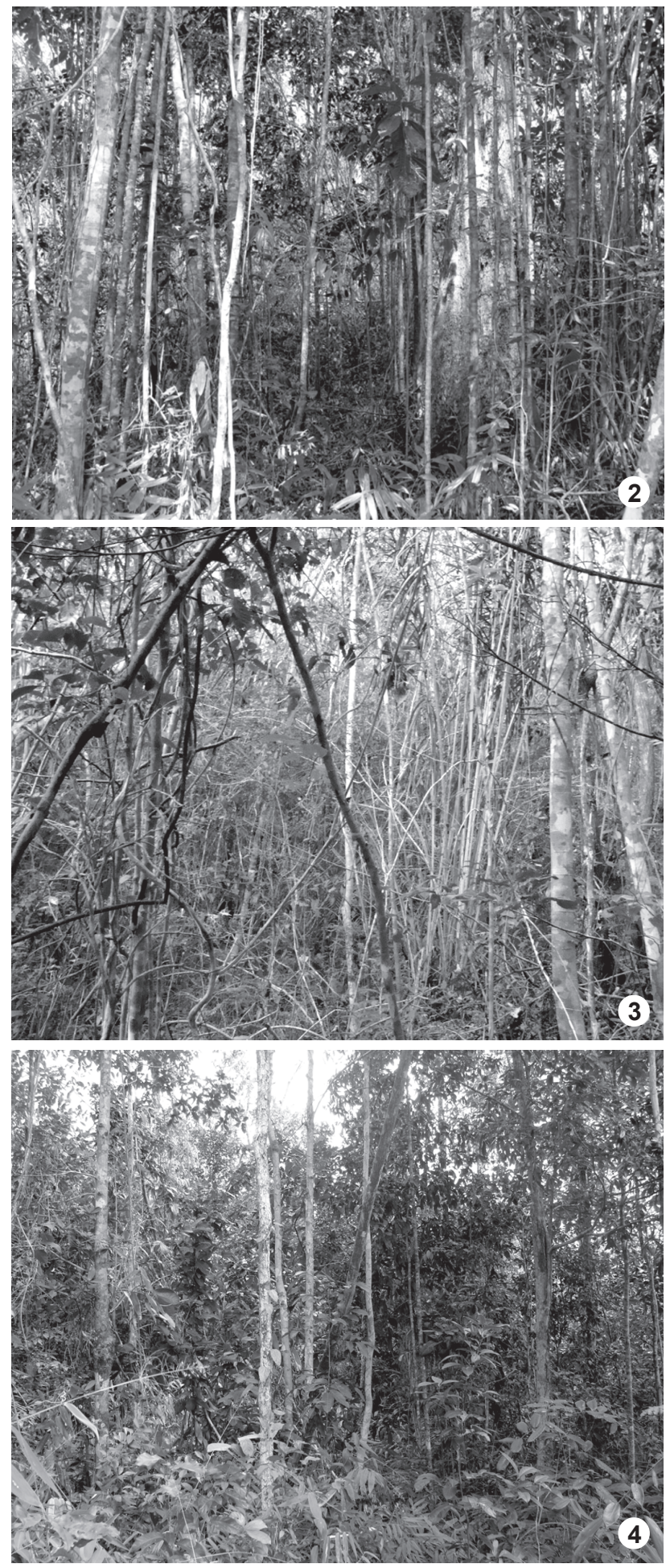

Figures 2-4. Examples of the three habitat categories identified in the present study: (2) mature forest; (3) secondary forest; (4) anthropogenic forest. 


\section{RESULTS}

\section{Habitat availability}

The habitat assessment revealed considerable variation among the four fragments (Tab. II). The relatively large proportion of anthropogenic habitat in Fragment 2 was obviously due to the recent fire at this site. Among the remaining three sites, there is a marked tendency for the larger fragments have a relatively better quality habitat, which might be related to the increased edge effects observed in smaller fragments, among other factors.

\section{Habitat use}

A total of 164 sightings of primates were recorded during the surveys (Tab. III), while only 15 sightings were recorded for all other mammals combined (R.R.D. Chagas, unpubl. data). Unexpectedly, the common marmoset was by far the rarest of the three species, providing just over ten percent of the sightings, a number only marginally adequate for the analyses conducted here. All three species were observed at least once in each fragment.

The comparison between the number of recorded and expected sightings (Tab. III) revealed that titis and marmosets both presented a certain preference for secondary habitat (Fig. $5)$ but it was not statistically significant $(p>0.05)$ in either case. By contrast, the capuchins avoided anthropogenic forest almost completely, and exhibited a strongly significant preference for mature habitat.

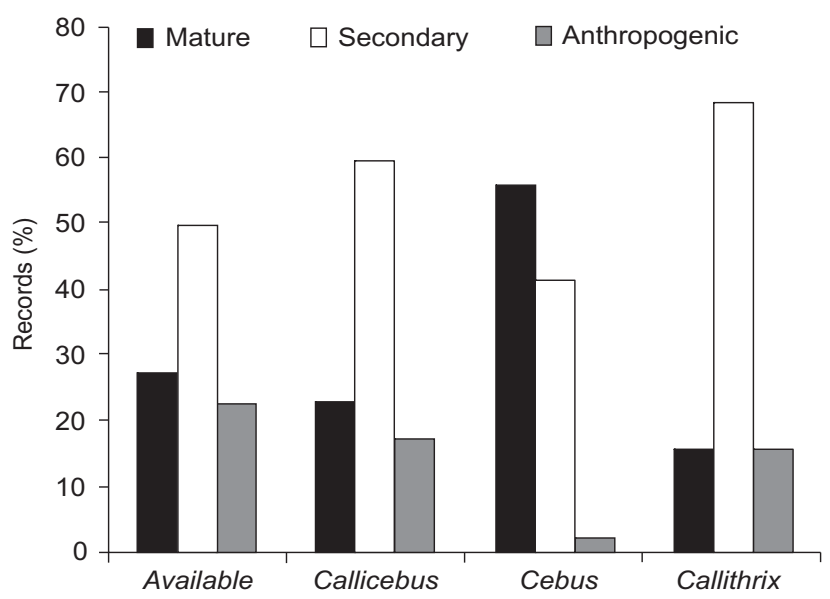

Figure 5. Habitat availability and use by each primate species during surveys at the Fazenda Trapsa.

While the reduced sample size prevents a more detailed analysis for Callithrix (Linnaeus, 1758), the number of Callicebus records does permit a comparison among fragments (Tab.IV). The results suggest that the titis had a significant preference for secondary over anthropogenic habitat in Fragment 2, which may reflect the avoidance of the latter, rather than a prefer- ence for secondary habitat. This is further reinforced by the results from Fragment 4, where anthropogenic habitat was not used, while both mature and secondary habitats were visited more than expected. In Fragment 1, by contrast, mature habitat was preferred over secondary forest.

However, the population density of the species was much greater in the smaller, more disturbed fragments (16.0-18.1 individuals per sq. km; RRDC, unpubl. data) than in the two larger ones (10.0-10.4 ind. $\left./ \mathrm{km}^{2}\right)$. The opposite appears to be true for C. xanthosternos, groups of which roamed freely among fragments, and would presumably have been observed more frequently in preferred fragments. In this case, the mean sighting rate in the two larger fragments was 1.1 sightings per $10 \mathrm{~km}$ walked, whereas it was $0.6 / 10 \mathrm{~km}$ in the two smaller fragments. The fragment with the highest sighting rate for Cebus Erxeleben, 1777 (Fragment 1) was that with the lowest density of Callicebus.

\section{Vertical spacing}

All three species tended to occupy the middle-lower strata of the forest (Fig. 6), although Callicebus and Cebus tended to occupy higher levels than Callithrix overall (Kruskal-Wallis: $\mathrm{K}=7.229, \mathrm{p}=0.027$, d.f. $=2$ ). For pairwise comparisons between species using the Dunn post-test, however, only Callicebus vs. Callithrix returned a significant difference $(\mathrm{p}<0.05)$. The lack of a clear pattern of vertical stratification is probably at least partly due to the relatively reduced stature of the forest. An interesting behavior not recorded during surveys was the titis and capuchins travelling over the ground at the study site.

When the records for $C$. coimbrai are analyzed by fragment (Fig. 7), an unexpected pattern emerges. While occupation of the highest strata was recorded only in the smallest fragment (3), the use of middle-level layers (6-8 m) was most frequent in the largest fragment (1). Overall differences are relatively subtle (Kruskal-Wallis: $\mathrm{K}=1.401, \mathrm{p}=0.7053$, d.f. $=3$ ) and possibly are due more to sampling effects than any functional difference among fragments.

\section{DISCUSSION}

Body size plays a fundamental role in the ecological differentiation of platyrrhines, and it appeared to underpin patterns of habitat use recorded in the present study. The preference of marmosets for disturbed habitat is well-known (Sussman \& Kinzey 1984, Digby et al. 2007), and while the results of this study indicate a certain preference for secondary habitat, the small number of records collected prohibited a more conclusive analysis. The unexpected rarity of Callithrix at the site may nevertheless point to specific ecological factors such as interspecific competition with Callicebus (see FerRari et al. 2003), which obviously demand further investigation.

While titis are also known to be relatively tolerant of habitat disturbance, the results of this study indicate that they do not necessarily prefer less well-preserved forest, and in fact, there was a tendency to avoid the most disturbed habitat, in 

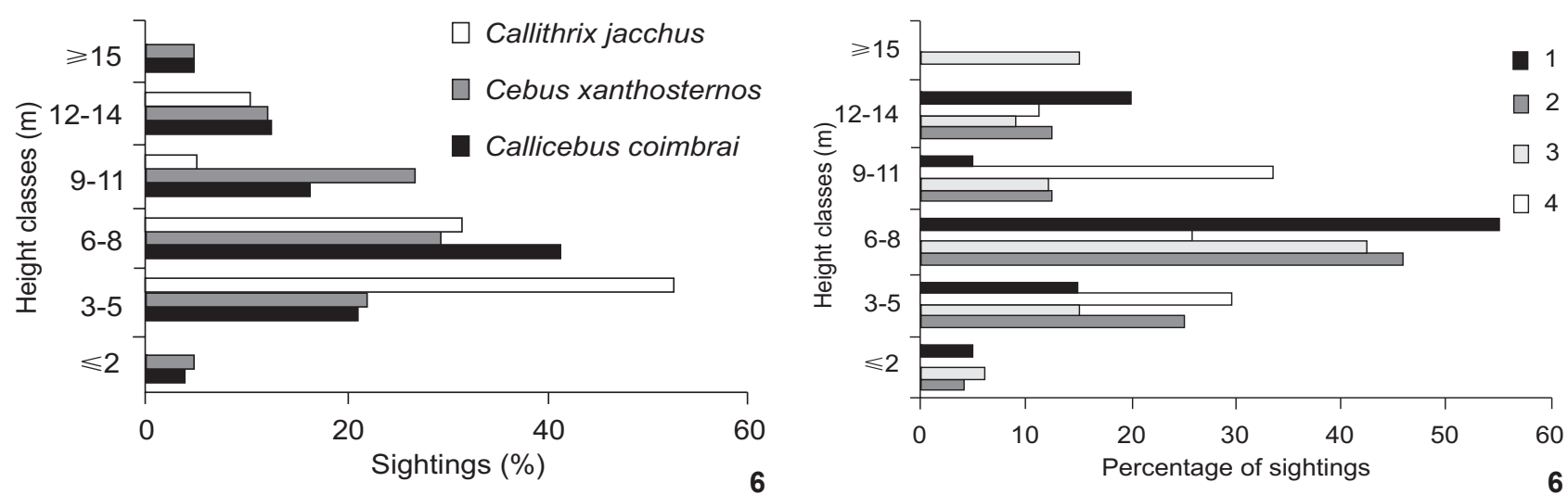

Figures 6-7. Relative frequency of height classes recorded for each primate species (6) and C. coimbrai (7) in the four fragments (Tab. II) sampled during surveys at the Fazenda Trapsa.

Table I. Habitat categories, adapted from Calouro \& PIRES (2004), used to classify the vegetation along the trail system in each of the four forest fragments at the Fazenda Trapsa.

\begin{tabular}{ll}
\hline \multicolumn{1}{c}{ Category } & \multicolumn{1}{c}{ Diagnosis } \\
\hline Mature & $\begin{array}{l}\text { Continuous canopy 12-15 m tall (occasionally } \geqslant 15 \mathrm{~m}) \text { with few gaps (<25\% of total area), relatively sparse } \\
\text { understory, low density of lianas and few pioneer trees (e.g. Cecropia spp.) }\end{array}$ \\
Recondary & $\begin{array}{l}\text { Relatively continuous canopy 8-10 m tall (25-75\% open), with well-developed understory, medium density of lianas } \\
\text { and pioneer trees }\end{array}$ \\
Anthropogenic & $\begin{array}{l}\text { Discontinuous canopy 5-10 m tall with frequent gaps ( }>75 \%), \text { very dense understory, high density of lianas and } \\
\text { pioneer trees }\end{array}$ \\
\hline
\end{tabular}

Table II. Estimated availability of the different habitats (Tab. I) in the four fragments surveyed during the present study.

\begin{tabular}{|c|c|c|c|c|c|c|}
\hline \multirow{2}{*}{ Fragment } & \multirow{2}{*}{ Area (ha) } & \multirow{2}{*}{$\begin{array}{l}\text { Transect length } \\
(\mathrm{km})\end{array}$} & \multirow{2}{*}{$\begin{array}{c}\text { Number of } \\
50 \mathrm{~m} \text { intervals }\end{array}$} & \multicolumn{3}{|c|}{ Availability (\%) of forest category } \\
\hline & & & & Mature & Secondary & Anthropogenic \\
\hline 1 & 118.2 & 2.5 & 50 & 50.0 & 48.0 & 2.0 \\
\hline 2 & 61.9 & 0.9 & 18 & 0.0 & 22.3 & 77.7 \\
\hline 3 & 61.0 & 1.3 & 26 & 3.9 & 73.0 & 23.1 \\
\hline 4 & 107.3 & 0.8 & 16 & 25.0 & 62.5 & 12.5 \\
\hline Total & 348.4 & 5.5 & 110 & 27.3 & 50.0 & 22.7 \\
\hline
\end{tabular}

Table III. Comparison of the number of sightings recorded (observed) and expected for each of the three primate species at the Fazenda Trapsa, according to the availability of different habitats.

\begin{tabular}{|c|c|c|c|c|c|}
\hline \multirow{2}{*}{ Species } & \multicolumn{3}{|c|}{ Number of records (observed/expected) } & \multirow{2}{*}{$\mathrm{N}$ records } & \multirow{2}{*}{$\chi^{2}(p)^{1}$} \\
\hline & Mature & Secondary & Anthropogenic & & \\
\hline Callicebus coimbrai & $24 / 28.4$ & $62 / 52.0$ & $18 / 22.6$ & 104 & $3.541(>0.100)$ \\
\hline Cebus xanthosternos & $23 / 11.1$ & $17 / 20.5$ & $1 / 9.3$ & 41 & $20.763(<0.001)$ \\
\hline Callithrix jacchus & $3 / 5.2$ & $13 / 9.5$ & $3 / 4.1$ & 19 & $2.515(>0.200)$ \\
\hline
\end{tabular}

1 for d.f. $=2$. 
Table IV. Comparison of the number of sightings recorded (observed) and expected for C. coimbrai in each of the four fragments at the Fazenda Trapsa, according to the availability of different habitats.

\begin{tabular}{ccccccc}
\hline \multirow{2}{*}{ Fragment } & \multicolumn{2}{c}{ Number of records (observed/expected) } & \multirow{2}{*}{ N records } & $\chi^{2}(\mathrm{p})$ \\
\cline { 2 - 4 } & Mature & Secondary & Anthropogenic & & $5.104(>0.05)^{1}$ \\
2 & $15 / 10.0$ & $5 / 9.6$ & $0 / 0.4$ & & 20 & $10.500(<0.01)^{2}$ \\
3 & - & $13 / 6.0$ & $14 / 21.0$ & 27 & 33 & $2.406(>0.05)^{1}$ \\
4 & $1 / 1.3$ & $28 / 24.1$ & $4 / 7.6$ & 24 & $3.733(>0.10)^{1}$ \\
\hline
\end{tabular}

${ }^{1}$ d.f. $=2 ;^{2}$ d.f. $=1$, with Yates' correction.

particular in fragment 2. The species was nevertheless more abundant in the smaller fragments. Atlantic Forest titis have been recorded in fragments of secondary forest (STAlLings \& Robinson 1991, Pinto et al. 1993, Heiduck 2002, São Bernardo \& Galettr 2004, Martins 2005), and Trevelin et al. (2007) found evidence of a preference for this type of habitat in Callicebus nigrifrons Spix, 1823. While this was not confirmed statistically in the present study, C. coimbrai does appear to be typical of the Atlantic Forest group.

By contrast, C. xanthosternos exhibited a clear predilection for the larger, better-preserved fragments, and a significant preference for mature forest over disturbed habitat. Capuchins are among the ecologically more flexible platyrrhines, and are tolerant of habitat fragmentation, although they appear to require much larger areas of forest than titis (Di BiтTETI 2001), due in part to differences in body size. This may explain the absence of C. xanthosternos from many of the sites Callicebus at which has been recorded in Sergipe (JERUSALINSKY et al. 2006). An additional local factor would be the absence from the surrounding matrix of crops such as maize and sugarcane, which may constitute an essential resource for many fragment-dwelling capuchins (FreItas et al. 2008).

MARTINs (2005) identified an apparent preference for secondary habitat in Cebus nigritus Goldfuss, 1809 in fragmented Atlantic Forest in southeastern Brazil, although in this case, the species was sympatric with two much larger-bodied platyrrhines, Alouatta guariba Humboldt, 1812 and Brachyteles arachnoids É. Geoffroy, 1806. At the present site the opposite was observed, with the relatively large capuchins preferring more mature habitats, within the same presumed context of niche partitioning.

The relatively low stature of the restinga forest at the study site preempted any more systematic analysis of vertical stratification in the three primate species, although all three genera are known to utilize the lower strata regularly at least at some sites (e.g. CunHa et al. 2006), and a preference for the lower levels in the forest has been recorded in a number of studies of Callicebus (Kinzey 1981, Palacios et al. 1997, Ferrari et al. 2000). SouZA-Alves \& FerRari (2010) also recorded the use of relatively low levels in the forest (below $10 \mathrm{~m}$ ) in an ecological study of $C$. coimbrai at the Fazenda Trapsa.
Obviously, the insights provided by the present study are limited in scope, but even preliminary data can provide an essential baseline for the conservation of endangered species (LAURANCE 1990). One important finding here was the apparent preference of Cebus for the better preserved habitat within the study area, which may represent an important component of niche partitioning with C. coimbrai, especially considering the rarity of sympatry between these two species in the region (R. Beltrão-Mendes, unpubl. data).

The ability to survive in fragments of secondary forest is likely an important asset for the conservation of all these species, but the ecological adaptations involved here are unclear. As both C. coimbrai and C. xanthosternos are essentially frugivorous, habitat fragmentation has potentially deleterious long-term implications (EsTrada \& COATES-EsTRADA 1996), although both genera are also known to exploit a wide range of alternative resources (ЈАСК 2007), and initial observations at the present study site (J.P. Souza-Alves, unpubl. data) indicate that C. coimbrai, like other titis, feeds on both leaves and arthropods.

\section{ACKNOWLEDGEMENTS}

We are especially grateful to Ary Ferreira, owner of Fazenda Trapsa, José Elias and João Pedro Souza-Alves for their assistance during fieldwork. João Pedro also provided the map and helpful comments on the manuscript. RRDC received a graduate stipend from the Deutscher Akademischer Austausch Dienst (DAAD), and SFF received financing from CNPq (302747/ 2008-7 and 476064/2008-2). We are also grateful to Kleber del Claro and two anonymous reviewers for their helpful comments on the original manuscript.

\section{LITERATURE CITED}

Arroyo-Rodriguez, V. \& P.A. Dias. 2010. Effects of habitat fragmentation and disturbance on howler monkeys: a review. American Journal of Primatology 72 (1): 1-16.

Blomquist, G. E.; M.M. Kowalewski \& S.R. Leigh. 2009. Demographic and morphological perspectives on life history evolution and conservation of New World primates, p. 117138. In: P.A. Garber; A. Estrada; J.C. Bicca-Marques; E.W. 
Heymann \& K.B. Strier (Eds). South American primates: comparative perspectives in the study of behavior, ecology, and conservation. New York, Springer.

Buckland, S.T.; D.R. Anderson; K.P. Burnham \& J.L. LaAKe. 2001. Distance sampling: estimating abundance of biological populations. London, Chapman and Hall, 432p.

Calouro, A.M. \& J.S.R. Pires. 2004. Caracterização de habitats para monitoramento de primatas na Floresta Estadual do Antimary (AC - Brasil), p. 187-195. In: Anais do Congresso Brasileiro de Unidades de Conservação. Curitiba, Fundação O Boticário de Proteção à Natureza; Rede Nacional PróUnidades de Conservação, ISSN 1677-1486.

Coimbra-Filho, A.F. \& I.G. CÂmara. 1996. Os limites originais do bioma Mata Atlântica na Região Nordeste do Brasil. Rio de Janeiro, Brazil, Fundação Brasileira para a Conservação da Natureza.

Cunha, A.A.; M.V. Vieira \& C.E.V. Grelle. 2006. Preliminary observations on habitat, support use and diet in two nonnative primates in an urban Atlantic forest fragment: The capuchin monkey (Cebus sp.) and the common marmoset (Callithrix jacchus) in the Tijuca forest, Rio de Janeiro. Urban Ecosyst 9 (4): 351-359.

Defler, T.R. 1994. Callicebus torquatus is not a white-sand specialist. American Journal of Primatology 33 (2): 149-154.

Di Biтteтi, M.S. 2001. Home-range use by the tufted capuchin monkey (Cebus apella nigritus) in a subtropical rainforest of Argentina. Journal of Zoology (London) 253 (1): 33-45.

Digby, L.J.; S.F. Ferrari \& W. Saltzman. 2007. Callitrichines: the role of competition in cooperatively breeding species, p. 85106. In: C.J. Campbell; A. Fuentes; K.C. MacKinnon; M. Panger \& S.K. Bearder (Eds). Primates in perspective. New York, Oxford University Press.

Estrada, A. \& R. Coates-Estrada. 1996. Tropical rain forest fragmentation and wild populations of primates at Los Tuxtlas. International Journal of Primatology 17 (5): 759 783.

Ferrari, S. F.; S. Inanaga; M.R. Messias; E.M. Ramos; P.C.S. Ramos; E.H. Cruz Neto \& P.E.G. Coutinho. 2000. Titi monkeys (Callicebus spp., Atelidae: Plathyrrini) in the Brazilian State of Rondônia. Primates 41 (2): 229-234.

Ferrari, S.F.; S. Iwanaga; A.L. Ravetta; F.C. Freitas; B.A.R. Sousa; L.L. Souza; C.G. Costa \& P.E.G. Coutinho. 2003. Dynamics of primate communities along the Santarém-Cuiabá highway in southern central Brazilian Amazonia, p. 123144. In: L.K. MARSH (Ed). Primates in Fragments. New York, Kluwer Academic.

Freitas, C. H.; E.Z.F. Setz; A.R.B. Araújo \& N. Gobbi. 2008. Agricultural crops in the diet of bearded capuchin monkeys, Cebus libidinosus Spix (Primates: Cebidae), in forest fragments in southeast Brazil. Revista Brasileira de Zoologia 25 (1): 32-39.

Heiduck, S. 2002. The use of disturbed and undisturbed forest by masked titi monkey Callicebus personatus melanochir is proportional to food availability. Oryx 36 (2): 133-139.
JACK, K.M. 2007. The cebines: towards an explanation of variable social structure, p. 107-123. In: C.J. Campbell, A. Fuentes, K. C. Mackinnon, M. Panger \& S. K. Bearder (Eds). Primates in perspective. New York, Oxford University Press.

Jerusalinsky, L.; M.M. Oliveira; R.F. Pereira; V. Santana; P.C.R. Bastos \& S.F. Ferrari. 2006. Preliminary evaluation of the conservation status of Callicebus coimbrai Kobayashi \& Langguth, 1999 in the Brazilian state of Sergipe. Primate Conservation 21 (1): 25-32.

Kierulff, M.C.M.; S.L. Mendes \& A.B. Rylands. 2008. Cebus xanthosternos. 2008 IUCN Red List of Threatened Species. Available online at: http://www.iucnredlist.org/details/4074/ 0 [Accessed: 20.X.2009]

KinzeY, W.G. 1981. The titi monkey, genus Callicebus, p. 241276. In: A.F. Coimbra-Filho \& R.A. Mittermeier (Eds). Ecology and Behavior of Neotropical Primates. Rio de Janeiro, Academia Brasileira de Ciências.

Kobayashi, S. \& A.B. Langguth. 1999. A new species of titi monkey, Callicebus Thomas, from north-eastern Brazil (Primates, Cebidae). Revista Brasileira de Zoologia 16 (2): 531-551.

LAURANCE, W.F. 1990. Comparative responses of five arboreal marsupials to tropical forest fragmentation. Journal of Mammology 71 (4): 641-653.

Marinho-Filho, J. \& E.W. Veríssimo. 1997. The rediscovery of Callicebus personatus barbarabrownae in northeastern Brazil with a new western limit for its distribution. Primates 38 (4): 429-433.

Martins, M.M. 2005. Density of primates in four semi-deciduous forest fragments of São Paulo, Brazil. Biodiversity and Conservation 14 (10): 2321-2329.

Palácios, E.; A. Rodriguez \& T.R. Defler. 1997. Diet of group of Callicebus torquatus lugens (Humboldt, 1812) during the annual resource bottleneck in Amazonian Colombia. International Journal of Primatology 18 (4): 503-522.

Pinto, L.P.S.; C.M.R. Costa; K.B. Strier \& G.A.B. Fonseca. 1993. Habitat, density and group size of primates in a Brazilian tropical forest. Folia Primatologica 61 (3): 135-143.

PorTER, L.M. 2004. Forest use and activity patterns of Callimico goeldii in comparison to two sympatric tamarins, Saguinus fuscicollis and Sanguinus labiatus. American Journal of Physical Anthropology 124 (2): 139-153.

São Bernardo, C.S. \& M. Galetti. 2004. Densidade e tamanho populacional de primatas em um fragmento florestal no sudeste do Brasil. Revista Brasileira Zoologia 21 (4): 827-832.

SCARANO, F.R. 2002. Structure, function and floristic relationships of plant communities in stressful habitats marginal to the Brazilian Atlantic rain forest. Annals of Botany 90 (4): 517 524.

Sousa, M.C.; S.S. Santos \& M.C.M. Valente. 2008. Distribuição e variação na pelagem de Callicebus coimbrai (Primates Pitheciidae) nos estados de Sergipe e Bahia, Brasil. Neotropical Primates 15 (2): 54-59. 
Stallings, J.R. \& J.G. Robinson. 1991. Disturbance, forest heterogeneity and primate communities in a Brazilian Atlantic forest park, p. 357-368. In: A.B. Rylands \& A.T. Bernardes (Eds). A Primatologia no Brasil. Belo Horizonte, Fundação Biodiversitas, vol. 3.

Souza-Alves, J.P. \& S.F. Ferrari. 2010. Responses of wild titi monkeys, Callicebus coimbrai (Primates: Platyrrhini: Pitheciidae), to the habituation process. Zoologia 27 (6): 861-866.

Sussman, R.W. \& W.G. Kinzey. 1984. The ecological role of the Callitrichidae: a review. American Journal of Physical Anthropology 64 (4): 441-449.

Submitted: 05.III.2010; Accepted: 26.VIII.2010.

Editorial responsibility: Kleber del Claro
Terborh, J. 1983. Five New World monkeys: a study in comparative ecology. Princeton, Princeton University Press.

Trevelin, L.C.; M. Port-Carvalho \& E. Morell. 2007. Abundance, habitat use and diet of Callicebus nigrifrons Spix (Primates, Pitheciidae) in Cantareira State Park, São Paulo, Brazil. Revista Brasileira de Zoologia 24 (4): 1071-1077.

van Roosmalen, M.G.M.; T. van Roosmalen \& R.A. Mittermeier. 2002. A taxonomic review of the titi monkeys, genus Callicebus Thomas, 1903, with the description of two new species, Callicebus bernhardi and Callicebus stephennashi, from Brazilian Amazonia. Neotropical Primates 10 (Suppl.): 1-52. 